\title{
The Effect of Montessori Method Supported by Social Skills Training Program on Turkish Kindergarten Children's Skills of Understanding Feelings and Social Problem Solving*
}

\author{
Gökhan Kayıl1 ${ }^{1}$, Ramazan Ar1 ${ }^{1}$ \\ ${ }^{1}$ Department of Child Development, Faculty of Health Sciences, Selcuk University, Konya, Turkey \\ Correspondence: Gökhan Kayıl1, Department of Child Development, Faculty of Health Sciences, Selcuk University, \\ Konya, Turkey.
}

Received: October 5, 2016

Accepted: November 3, 2016

Online Published: November 7, 2016

doi:10.11114/jets.v4i12.1965

URL: http://dx.doi.org/10.11114/jets.v4i12.1965

\begin{abstract}
The current research was conducted with the purpose of analyzing the effect of Montessori method supported by Social Skills Training Program on kindergarten children's skills of understanding feelings and social problem solving. 53 children attending İhsan Doğramacı Applied Nursery School affiliated to Selcuk University, Faculty of Health Sciences in Konya during 2013-2014 school year were included in the study group. Wally Feelings Test and Wally Social Problem Solving Test were used as data collection tools. The tests were applied to the children as pre and post-test. In addition, the tests were applied to the experimental group again six weeks after the end of the educational program. Kruskal Wallis H test and Wilcoxon Signed Rank Test were used for the analysis of the data. When findings were analyzed comparing post-test scores of Wally Feelings Test and Wally Social Problem Solving Test of experimental and control groups 1 and 2, it was found that there was a significant difference in favour of the experimental group. When comparing the post and follow-up test scores of Wally Feelings Test and Wally Social Problem Solving Test of the experimental group, it was seen that there was no significant difference. In conclusion, the study results showed that Montessori method supported by Social Skills Training Program supports the development of children's skills of understanding feelings and social problem solving.
\end{abstract}

Keywords: social skill training programs, understanding feelings, social problem solving, Montessori method

\section{Introduction}

Preschools exist in the education system of countries as the institutions supporting children in order to prepare them for social life and environment (Durualp and Aral, 2010). The activities presented through preschool programs play a role in children's participation in groups, healthy communication with others, acquisition of essential habits, expression of feelings in a comfortable manner and enhancement of social and pro-social skills such as sharing, cooperation and helping each other. Today, studies largely focus on how to extend preschool services and increase their qualities rather than emphasizing how important it is to provide an environment with rich stimuli and introduce planned activities (Toran, 2011). In order to provide quality service in preschool education, it is highly important to improve the quality of preschool staff, physical conditions and educational programs as well as promoting investments and making healthy policies and planning (Temel, 2005).

Studies conducted on early childhood programs and practices have made a contribution to the emergence of novel models in preschool education. Though earlier ones were European based models, they have spread across the world over time and led to the emergence of new models. Several progressive approaches born in Europe such as Waldorf, Montessori and Reggio Emilia have influenced not only the whole Europe but the regions outside Europe, as well. Some other approaches such as Head Start, High Scope and Bank Street emerged in the USA after 1950s as a result of the efforts to support preschool education and improve children's adaptation to society. These modern approaches have a common goal related to the quality of the education to be provided to children (Thomas, 2008; Toran, 2011). Among these approaches, Montessori method is also used as an alternative education model in some university nursey schools

*This paper was derived from the first author's Doctoral Dissertation 
and some private preschools in Turkey just like the way it is in the world. The reasons are that Montessori method is a child-based method and it emphasizes the specially-arranged environment that allows freedom for children, provides opportunities for children to learn by practising and experiencing, values family involvement and offers individualized education (Çakıroğlu Wilbrandt, 2011; Kayılı and Arı, 2011; Morrison, 2007; Toran, 2011). Criticisms against Montessori method mainly include specially arranged environment, mixed age groups, its focus on child's attention within small groups and individualized education practices. This different educational perspective of Montessori method let researchers and parents think that it has negative effects on child's social skills or it makes no difference compared to other preschool models (Castellanos, 2002; Chou, 2004; De Vries and Göncü, 1987; Flynn, 1991; Gleen, 2003; Hobbs, 2008; Kayılı and Kuşcu, 2012; Keçecioğlu, 2015; Koçyiğit and Kayılı, 2008; Korkmaz, 2005; Rathunde and Csikszentmihalyi, 2005).

The expansion in the social environment of children occurring especially with starting a school allows them to learn how to arrange their relationships and how to resolve interpersonal problems and it also helps them put into practice what they have already learned. The skills of problem solving and understanding feelings arise as an important determinant for adjustment during this developmental stage (Biggam and Power, 1999; Shure and Spivack, 1982; Yaban and Yükselen, 2007). As children's social skills improve, their problem-solving skills also develop and they learn to work out new strategies (Rubin and Krasnor, 1986). Solving social problems requires developing the skills children need to communicate with their environment and also the ability to accurately understand feelings of their own and others (Yaban and Yükselen, 2007). Social skills are the behaviors that children can learn by means of appropriate teaching principles and effective programs (Avcioğlu, 2005; Dereli, 2008; Durualp and Aral, 2010; Reid, Webster-Stratton and Hammond, 2007; Webster-Stratton, Reid and Hammond, 2001; Webster-Stratton and Reid, 2004). Social Skills Training Program is one of these programs. Social Skills Training Program facilitates children's adaptation to their environment by allowing their social development and developing their ability to understand feelings and their social problem solving skills which are necessary for them to communicate with their environment. Previous research showed that children incapable of understanding feelings and solving social problems are more open to experiences such as rejection by their peers, adjustment and communication problems, low academic scores, lack of cooperation with others, problem behaviors and social isolation (Ar1 and Yaban, 2012; Coie and Dodge, 1998; Parker and Asher, 1993; Werner and Crick, 2004). For that reason, children's social development needs to be supported by further training and supplementary programs.

This study focuses on the effect of Montessori Method supported by social skills training program on preschool children's ability to understand feelings and their social problem solving skills. Accordingly, three different groups attending a preschool were selected for the study; a) Pure-Montessori Group, b) Montessori Group supported by Social Skills Training Program and c) State-Program Group - receiving the Preschool Education Program developed by the Ministry of National Education, Republic of Turkey (MNE).

\section{Method}

\subsection{Design of the Study}

This study was conducted as a pretest/posttest control group experimental design. In the research design, the dependent variable is preschool children's skills of understanding feelings and their social problem-solving skills. Montessori method supported by social skills training program is the independent variable. Children in the experimental group received preschool education based on the Montessori method supported by social skills training program. Children in the Control Group 1 were instructed by pure Montessori method while children in the Control Group 2 learnt through MNE Preschool Education Program.

\subsection{Sample of the Study}

For the sample of study, the programs provided to 36-60 month-old children in the nursery school were taken into account. There are two types of preschool education program provided in the school; A- Preschool Education Program developed by the Ministry of National Education (MNE Program, one group), B- Montessori-based Program (two groups). One of two Montessori groups was randomly assigned as the Pure-Montessori Group (Control Group 1) and the other as the Montessori Group supported by Social Skills Training Program (Experimental Group). The group receiving MNE program was assigned as the second control group (Control Group 2).

The reason for choosing the above-mentioned school is because it offers different preschool programs (MNE program and Montessori program are provided independently in different groups), it has appropriate physical conditions, school administration is willing to cooperate and the school serves as a lab in the field of child development and education.

For the study groups, classes offering preschool education to 36-60 month-old children at İhsan Doğramac1 Applied Nursery School affiliated to Selcuk University Faculty of Health Sciences were included. Experimental and Control 1 
Groups were formed based on the random cluster sampling method. Since there is only one class receiving MNE program, all children in this program were assigned to Control Group 2. A total number of 53 children were included in the study; 18 in the Experimental group, 19 in Control Group 1 and 16 in Control Group 2.

Gender distribution of experimental and control groups were given in Table 1.

Table 1. Gender distribution of children in experimental and control groups

\begin{tabular}{|c|c|c|c|c|c|c|}
\hline \multirow[t]{2}{*}{ Gender } & \multicolumn{2}{|c|}{ Experimental Group } & \multicolumn{2}{|c|}{ Control Group 1} & \multicolumn{2}{|c|}{ Control Group 2} \\
\hline & $\mathrm{n}$ & $\%$ & $\mathrm{n}$ & $\%$ & $\mathrm{n}$ & $\%$ \\
\hline Girls & 10 & 55.6 & 6 & 31.6 & 11 & 68.8 \\
\hline Boys & 8 & 44.4 & 13 & 68.4 & 5 & 31.2 \\
\hline Total & 18 & 100 & 19 & 100 & 16 & 100 \\
\hline
\end{tabular}

As seen in Table 1, in the experimental group there are 10 girls (\%55.6) and 8 boys (\%44.4); 6 of the children (\%31.6) are girls and 13 (\%68.4) are boys in the control group 1 and the numbers of girls and boys are 11 (\%68.8) and 5 (\%31.2) respectively in the control group 2. Besides, the arithmetic mean of age is ( $X$ ) 3.61 years for the experimental group, 3.68 years for the control group 1 and 3.63 years for the control group 2. Preschool duration of the children was also checked since it was likely to affect the results of the study. It was found that the average school duration was $(\bar{X}) 1.44$ years for the children in the experimental group, 1.52 years for those in the control group 1 and 1.43 years for the control group 2.

Wally Feelings Test - which is used to assess children's ability to understand feelings - was administered to the children in order to see whether the experimental and control groups were similar at the baseline and pre-test mean scores of the groups were presented in Table 2.

Table 2. Pre-test scores of experimental and control groups on Wally Feelings Test

\begin{tabular}{|c|c|c|c|c|c|c|c|c|}
\hline Group & $\mathrm{n}$ & $\bar{X}$ & SS & Mean Rank & $\mathrm{sd}$ & $\mathrm{X}^{2}$ & $\mathrm{p}$ & Significance \\
\hline Experimental Group & 18 & 4.33 & 1.13 & 30.31 & 2 & 2.502 & .289 & - \\
\hline Control Group 1 & 19 & 4.15 & 1.89 & 27.89 & & & & \\
\hline Control Group 2 & 16 & 3.50 & 1.75 & 22.22 & & & & \\
\hline
\end{tabular}

As shown in Table 2, pre-test mean ranks of three groups on Wally Feelings Test were compared using Kruskal Wallis $\mathrm{H}$ Test. The ranks obtained for each group are as follows; experimental group $=30.31$, control group $1=27.89$ and control group $2=22.22$. The $X^{2}$ value $(2.502)$ was computed and found to be insignificant; $X^{2}(s d=2, n=53)=2.502$, $\mathrm{p}>.05$. That means, there was no significant difference between the pre-test scores of experimental and control groups and they were statistically equivalent.

The data in Table 3 shows the results of pre-test mean scores that children achieved on Wally Social Problem Solving Test, which is used to measure children's social problem solving skills.

Table 3. Pre-test scores of experimental and control groups on Wally Social Problem Solving Test

\begin{tabular}{|c|c|c|c|c|c|c|c|c|}
\hline Group & $\mathrm{n}$ & $X$ & SS & Mean Rank & sd & $\mathrm{X}^{2}$ & $\mathrm{p}$ & Significance \\
\hline Experimental Group & 18 & 6.94 & 2.23 & 30.17 & 2 & 1.200 & .549 & - \\
\hline Control Group 1 & 19 & 6.10 & 3.08 & 24.89 & & & & \\
\hline Control Group 2 & 16 & 6.31 & 2.67 & 25.94 & & & & \\
\hline
\end{tabular}

Pre-test mean ranks of three groups on Wally Social Problem Solving Test were compared using Kruskal Wallis H Test, as can be seen in Table 3. The mean rank calculated for the children in the experimental group was 30.17 while it was 24.89 and 25.94 for the control group 1 and 2 respectively. The analysis performed for $\mathrm{X}^{2}$ value (1.200) showed that it was not significant; $X^{2}(s d=2, n=53)=1.200, p>.05$. Accordingly, there was no significant difference between the pre-test scores of experimental and control groups on Wally Social Problem Solving Test and the groups were statistically equivalent.

\subsection{Data collection Instruments}

\subsubsection{Wally Feelings Test}

Wally Feelings Test is used to measure children's ability to understand feelings, it was developed within the scope of the project "Incredible Years" which was founded by Carolyn Webster-Stratton in the Parenting Clinic at the University of Washington. In this test, children are shown eight pictures of positive and negative situations and are asked how the characters in the pictures feel. The hypothetical situations in the test are pictured in two different forms to be suitable for the gender of test taker. That is, girls are tested using pictures with female characters while boys are tested using pictures with male characters (Dereli, 2008; Webster-Stratton, 1990; Webster-Stratton, Reid and Stoolmiller, 2008; Webster-Stratton, Reid and Beauchaine, 2013).

They get one (1) point when children correctly identify the feelings the characters in pictures would feel in positive and negative situations and they get zero (0) point when they identify the feelings incorrectly or cannot identify at all. The 
sum of the points obtained from all hypothetical situations provides the total score. In the test, the highest and the lowest possible scores are eight (8) and zero (0), respectively. Emotion vocabulary codes are used to determine which feeling words used by the child are acceptable and which are not acceptable. The response is considered correct and the child gets one (1) point if she/he chooses any word from the code list across the test item to identify the feeling depicted in the relevant situation; if the response provided by the child is not in the code list, the child gets zero (0) point. In the present study, Kaiser-Meyer-Olkin (KMO) coefficient was found to be .787 for Wally Feelings Test and Bartlett's test of Sphericity performed for Wally Feelings Test was found significant $\left(X^{2}=948.677 ; p<.001\right)$. Consequently, results indicated fitness of the data for the factor analysis. The results of the factor analysis showed that items including 8 hypothetical situations of the test were grouped under a single factor. The proportion of the variance explained by this single factor was $\% 35.478$. Given the common threshold of $30 \%$, the results indicated that the test had a single factor (Çokluk, Şekercioğlu and Büyüköztürk, 2010). Principal Components Analysis showed that factor loadings of items ranged from .47 to .63. Büyüköztürk (2012) suggests that items with factor loading of .30 or higher can discriminate well an individual from another.

For its concurrent validity, Wally Feelings Test was compared to the Assessment of Children's Emotional Skills Identification of Emotions (Durmuşoğlu Saltalı, Deniz, Çeliköz and Arı, 2009), which is a reliable and valid measure. 31 children were included in the concurrent validity study. Tests were administered to the children individually in two sessions - with a two-day break. A positive and significant relationship was found between children's scores on Wally Feelings Test and the Assessment of Children's Emotion Skills - Identification of Emotions r $=0.743, \mathrm{p}<.01$.

Kuder Richardson-20 (KR-20) formula was used to measure the internal consistency of Wally Feelings Test. The reliability coefficient of Wally Feelings Test was found to be $.76(n=50)$ for 3 year-old children, $.84(n=145)$ for 4 year-old children and $.80(\mathrm{n}=504)$ for 5 year-olds. For a psychological test, a reliability coefficient of .70 and higher is considered satisfactory for the reliability of test scores (Büyüköztürk, 2012). Accordingly, KR-20 reliability coefficients calculated separately for each group provided evidence for the reliability of Wally Feelings Test.

Results of the split-half test reliability showed that reliability coefficients calculated for each group were as follows; .78 $(\mathrm{n}=50)$ for three-year old children, $.77(\mathrm{n}=145)$ for four-year olds and $.72(\mathrm{n}=504)$ for five-year olds. These values show that split-half reliability coefficient of the test is adequate.

For the test-retest reliability, Wally Feelings Test was administered to 28 children twice with four weeks break and the consistency of children's responses to each item was analyzed. Consistencies between the first and second measure were calculated individually for all participants. The lowest and the highest consistency ratios between the first and second measure were .50 and .87 , respectively. The average consistency ratio was found to be .73 . The data obtained suggests that test-retest reliability of Wally Feelings Test is satisfactory.

\subsubsection{Wally Social Problem Solving Test}

Wally Social Problem Solving Test is used to measure social problem solving skills of the children in the study group, it was derived from Spivack and Shure's (1985) Preschool Problem Solving Test and Rubin and Krasnor's (1986) Child Social Problem Solving Test. This test was developed within the scope of the project "Incredible Years" which was founded by Carolyn Webster-Stratton in the Parenting Clinic at the University of Washington (Webster-Stratton, 1990; Webster-Stratton, Reid and Beauchaine, 2013). It measures children's problem solving skills by analysing their responses to the conflicts arising from hypothetical interpersonal relationships. Test has two different forms designed for girls and boys. Both forms have 15 pictures depicting conflicts or problems in interpersonal relationships. In the form for boys, the child in the hypothetical situation is a boy and the character in the form for girls is a girl. Each of the 15 pictures depicting hypothetical situations is shown to the child and after each picture the child is asked what s/he would do or say to solve the problem if they faced such a problem. Children are encouraged to respond as many questions as possible.

On the test, the hypothetical situations presented to children cover 11 themes. These are rejection, making a mistake, unjust treatment, victimization, prohibition, loneliness, being cheated, disappointment, dilemma, adult disapproval and attack (Dereli, 2008; Giren, 2013; Y1lmaz, 2012).

Wally Social Problem Solving Test presents to the children 15 coloured pictures with hypothetical problems and asks what they would do when they face such a problem. Each response of the child is coded and recorded after comparing them to the solution strategies within the prosocial and agonistic categories of Wally's Test. The recorded responses are scored on the scoring sheet as positive $(\mathrm{P})$, negative $(\mathrm{N})$ or not scorable (left blank). Each prosocial response of the child is scored as positive, each antisocial response as negative and those unresponded ones are scored as not scorable. For each positive response the child gets one (1) point while negative and not scorable responses are given a point of zero (0). On the test, the highest and the lowest scores are fifteen (15) and zero (0), respectively. 
It the present study, KMO coefficient for Wally Social Problem Solving Test was calculated to be .814 . The result of Bartlett Sphericity test was found significant $\left(X^{2}=1164.354 ; p<.01\right)$. Based on the results obtained, it was seen that the dataset was appropriate for factor analysis. Factor analysis revealed that 15 items on Wally social Problem Solving Test were combined into a single factor. Explanatory rate of a single factor is $46 \%$. Given the common threshold of $30 \%$, the results showed that the test had one factor. Factor loads of the items were examined according to Principal Components Analysis and it was found that factor loads of the items ranged between .34 and .67 .

Richardson-20 (KR-20) formula was used to measure the internal consistency of Wally Social Problem Solving Test. The reliability coefficient of Wally Social Problem Solving Test was found to be $.72(\mathrm{n}=50)$ for 3 year-old children, .79 $(\mathrm{n}=145)$ for 4 year-old children and $.81(\mathrm{n}=504)$ for 5 year-olds.

Results of the split-half test reliability showed that reliability coefficients calculated for each group were as follows; .69 $(n=50)$ for three-year old children, $.74(n=145)$ for four year olds and $.77(n=504)$ for five-year olds. Spearman Brown coefficients calculated for each age group show that split-half reliability coefficient of the test is adequate.

For the test-retest reliability, Wally Social Problem Solving Test was administered to 28 children twice with four weeks break and the consistency of children's responses to each item was analyzed. Consistencies between the first and second measure were calculated individually for all participants. The lowest and the highest consistency ratios between the first and second measure were .66 and .93 , respectively. The average consistency ratio was found to be .77 . The data obtained confirms that test-retest reliability of Wally Social Problem Solving Test is satisfactory.

\subsection{Social Skills Training Program Administered to Experimental Group}

Developed by Webster-Stratton (1990), this classroom-based program was intended for children between 3 and 8 years old and has three different versions. These are nursery school, nursery classes and primary school (Grade 1-3) versions. This study used the nursery school version developed for 3 to 5 years old children. The program consists of 64 lesson plans and over 300 activities. Moreover, it includes "Dinosaur Homework Activities" that parents do with their children which is intended to increase parental involvement and support children's skills at home. The program is implemented twice a week at least and a single lesson plan includes 15 to 20-minute large group activities and 20-minute small group activities which are performed following the large group activities. Parents are sent letters on regular basis about the concepts and the skills that are taught to children at school and parents are encouraged to participate in classroom activities. The program focuses on seven units; learning the rules, success at school, emotional and empathetic skills, social problem solving, anger management, friendship and communicative skills (Webster-Stratton and Reid, 2004; Webster-Stratton, 2012).

\subsection{Analysis of the Data}

To analyze the data obtained from both Wally Tests, two non-parametric tests - Kruskal Wallis H and Wilcoxon Signed Rank Test - were used to compare independent and dependent sample groups, respectively. The significance of the difference between the scores was tested at .05 significance level.

\section{Results}

The Kruskal Wallis $\mathrm{H}$ test was applied to determine whether there was a significant difference between post-test scores of the experimental and control groups on Wally Feelings Test and the results were presented in Table 4.

Table 4. Kruskal Wallis $\mathrm{H}$ test results for post-test scores of experimental and control groups on wally feelings test

\begin{tabular}{|c|c|c|c|c|c|c|c|c|}
\hline Group & $\mathrm{n}$ & $X$ & SS & Mean Rank & sd & $x^{2}$ & $\mathrm{p}$ & Significance \\
\hline Experimental & 18 & 7.88 & .32 & 42.44 & 2 & 29.013 & .000 & $\mathrm{~A}-\mathrm{B}, \mathrm{A}-\mathrm{C}^{*}$ \\
\hline Control 1 & 19 & 5.57 & 1.57 & 19.37 & & & & \\
\hline Control 2 & 16 & 5.50 & 1.36 & 18.69 & & & & \\
\hline
\end{tabular}

*A= Experimental Group, $\mathrm{B}=$ Control Group 1, $\mathrm{C}=$ Control Group 2

As shown in Table 4, Wally Feelings Test post-test scores in the experimental group are statistically significantly higher than those in the control groups 1 and 2. Kruskal Wallis $\mathrm{H}$ Test revealed that the difference between the groups was statistically significant, $x^{2}(\mathrm{sd}=2, \mathrm{n}=53)=29.013, \mathrm{p}<.05$. Mann Whitney $\mathrm{U}$ test was performed in order to establish between which two groups the significant difference occurred and it was seen that post-test scores of the children in the experimental group were significantly different from the scores achieved in the control groups 1 and 2.

In the study, post-test scores of experimental and control groups on Wally Social Problem Solving Test were compared using Kruskal Wallis H Test to find out if there was a significant difference and the results were presented in Table 5. 
Table 5. Results of the Kruskal Wallis H Test for post-test scores of experimental and control groups on Wally Social Problem Solving Test

\begin{tabular}{|c|c|c|c|c|c|c|c|c|}
\hline Group & $\mathrm{n}$ & $\bar{X}$ & SS & Mean Rank & sd & $x^{2}$ & p & Significance \\
\hline Experimental & 18 & 14.22 & 1.06 & 44.08 & 2 & 34.866 & .000 & A-B, A-C* \\
\hline Control 1 & 19 & 9.77 & 2.73 & 19.66 & & & & \\
\hline Control 2 & 16 & 9.68 & 1.01 & 16.50 & & & & \\
\hline
\end{tabular}

*A= Experimental Group, $\mathrm{B}=$ Control Group 1, $\mathrm{C}=$ Control Group 2

It is seen in Table 5 that post-test scores that children in the experimental group achieved on Wally Social Problem Solving Test are statistically significantly higher than the scores obtained by those in the control groups 1 and 2 . Kruskal Wallis $\mathrm{H}$ Test showed that the difference between the groups was statistically significant, $x^{2}(\mathrm{sd}=2$, $\mathrm{n}=53)=34.866, \mathrm{p}<.05$. Mann Whitney $\mathrm{U}$ test was performed in order to determine between which two groups the significant difference occurred and it was seen that post-test scores of the children in the experimental group were significantly different from the scores recorded in the control groups 1 and 2.

To test whether the difference was significant between the post- and follow-up test (performed six weeks after the completion of intervention) scores of the experimental group children, Wilcoxon Signed Rank Test was conducted and the results of the comparison were presented in Table 6.

Table 6. Results of the Wilcoxon Signed Rank Test for post- and follow-up test scores of the experimental group on Wally Feelings Test

\begin{tabular}{lccccc}
\hline & $\mathrm{n}$ & Mean Rank & Sum of Ranks & $\mathrm{z}$ & $\mathrm{p}$ \\
\hline Negative Rank & 3 & 3.00 & 3.00 & 6.00 & $-.447 *$ \\
Positive Rank & 2 & & & \\
Ties & 13 & 18 & & & \\
Total & 18 & & & \\
\hline
\end{tabular}

*Based on Positive Rank

According to the data in Table 6, no significant difference was observed in $z$ score when post- and follow-up test scores of the children were compared ( $\mathrm{z}=-.447, \mathrm{p}>.05)$. Given the mean rank and sum of ranks, it was seen that there was a decline in Wally Feelings Test scores of three children in the experimental group but this did not lead to a significant difference between the mean ranks of post- and follow-up tests. This finding suggests that Montessori method supported by Social Skills Training Program has produced a lasting impact on children's skills of understanding feelings.

To test whether the difference was significant between the post- and follow-up test (performed six weeks after the completion of intervention) means of the experimental group children on Wally Social Problem Solving Test, Wilcoxon Signed Rank Test was performed and the results were presented in Table 7.

Table 7. Results of the Wilcoxon Signed Rank Test for post- and follow-up test scores of the experimental group on Wally Social Problem Solving Test

\begin{tabular}{lccccc}
\hline & $\mathrm{n}$ & Mean Rank & Sum of Ranks & $\mathrm{z}$ & $\mathrm{p}$ \\
\hline Negative Rank & 2 & 4.75 & 9.50 & $-.776^{*}$ & \\
Positive Rank & 5 & 3.70 & 18.50 & \\
Ties & 11 & & & \\
Total & 18 & & & \\
\hline
\end{tabular}

* Based on Negative Rank

As seen in Table 7, there was no significant difference in $z$ score when post- and follow-up test scores of the children were compared ( $\mathrm{z}=-.776, \mathrm{p}>.05)$. Given the mean rank and sum of ranks, it was seen that there was a decline in Wally Social Problem Solving Test scores of two children in the experimental group but this did not cause a significant difference between the mean ranks of post- and follow-up tests. This finding confirms that Montessori method supported by Social Skills Training Program has produced a lasting impact on social problem solving skills of children in the experimental group.

\section{Discussion and Interpretation}

In order to see the effect of Montessori method supported by Social Skills Training Program on preschool children's skills of understanding feelings and social problem solving, post-test mean scores that the children in the experimental, control 1 and 2 groups achieved on Wally Feelings and Social Problem Solving Skills Tests were compared. Children in the experimental group received Montessori education supported by social skills training program while those in the control groups followed the pure Montessori way of learning and MNE Preschool Program. The difference was found significant at the .05 level between the post-intervention mean scores that experimental and control groups achieved on Wally Feelings and Social Problem Solving Skills Tests. Based on this finding it might be suggested that this difference 
was not due to the development of children and the basic education programs implemented in the classes (Montessori and MNE Preschool Program), but was due to the supportive social skills training program which probably affected children's skills of understanding feelings and social problem solving. In other words, there was an increase in children's levels of understanding feelings and social problem solving thanks to the social skills training program.

One of the crucial changes in early childhood occurs in the emotional world of children. In this period, children gradually develop skills that help them be aware of and understand the feelings of others and their own (Santrock, 2015). As reported by Dunn and Hughes (1998), it is really important for the maintenance of social relationships that children can understand the feelings of their peers with whom they interact socially. The skills of understanding feelings are considered to be an important prerequisite for children's social development (Webster-Stratton and Reid, 2004; Webster-Stratton, 2012). In the literature, there are many studies that support the findings of the present study with a conclusion that social skills training programs focusing on the improvement of emotional skills have a positive impact on children's social skills (Gunter, Calderalla, Korth and Young, 2012; Kramer, Calderalle, Christensen and Shatzer, 2010; Powless and Eliot, 2002; Webster-Stratton and Reid, 2004).

According to Webster-Stratton and Reid (2004), there are three different approaches to teach children social skills and support their emotional skills. These are parent training, teacher training and child training which includes direct practices with children. Of these, the last one - doing direct practices with children - is the most common approach and this can be achieved by means of preschool education programs. Today, there are many different types of preschool education approaches. All known early childhood education programs intend to support all developmental areas of children. The basic philosophy underlying the Montessori method is that it prepares children for the real life by making them independent from adults. For that reason, it is one of the main goals to make children individuals who can solve their problems independently by supporting them in all developmental areas. There is a body of experimental and longitudinal research reporting positive effects of Montessori method on children's academic and concentration skills and cognitive, language and psycho-motor development and there is a common consensus among researchers on this issue (Ansari and Winsler, 2014; Byun, Blair and Pate, 2013; Franc and Subotic, 2015; He, Yan, Zuo, Liu and Zhang, 2009; Jarvis, 2015; Kayılı and Arı, 2011; Kayıl1, Koçyiğit and Erbay, 2009; Koçyiğit, Kayılı and Erbay, 2010; Lopata, Wallace and Finn, 2005; Toran, 2011; Yıldırım Doğru, 2015; Yiğit, 2008). On the other hand, there are also studies with different findings about the effect of Montessori method on children's social skills (Castellanos, 2002; Chou, 2004; DeVries and Göncü, 1987; Flynn, 1991; Hobbs, 2008; Kayılı and Kuşcu, 2012; Keçecioğlu, 2015; Koçyiğit and Kayıll, 2008). Findings of the present study bring forward that Montessori method needs to be used along with social skills training program so that children's social skills can be enhanced. Besides, criticisms against Montessori method vary as specially arranged environment, mixed age groups, its focus on child's attention within small groups and individualized education practices. This different educational understanding of Montessori might lead researchers and parents to think that it has negative effects on child's social skills or it does not make a difference when compared to other preschool models (Castellanos, 2002; Gleen, 2003; Keçeçioğlu, 2015; Rathunde and Csikszentmihalyi, 2005). The study conducted by Keçecioğlu (2015) kind of supports this belief. Keçecioğlu (2015) examined the social skills of five-year old children who were taught through either MNE preschool program or Montessori method. In the study, no statistically significant difference was found between the groups in the self expression and self-control mean scores of the social skills scale while a difference was observed in the cooperation subscale in favour of the children who used MNE Preschool Program. Besides, though it is asserted that the mixed age group model in Montessori method supports children's social development, it is not adequate alone (Hendron, 2011) and activities supporting social and emotional development need to be integrated with the daily program.

In this study, Montessori method was used as combined with social skills training program which was developed as a classroom-based approach by Webster-Stratton (1990). This program is aimed at improving children's social skills by supporting social problem solving and emotional skills. The methods followed in the program might be the reason why the children in the experimental group achieved higher scores in understanding feelings and social problem solving skills when compared to the children in control 1 and 2 groups. Rather than direct skills teaching, methods such as cooperative learning, peer-mediated learning, modelling and video modelling, drama, role playing and coaching were used in the program. Also, family letters and at-home activities were benefitted to support skills in the home environment.

There exist in the literature some research results confirming the effectiveness of the social skills training program which is implemented in an eclectic way and aimed at developing emotional skills. Powless and Eliot (2002) reported that the Head Start Program supported by social skills training is influential in children's emotional development and developing terminal social behaviours. A review of literature showed studies with similar findings about the effectiveness of the training programs implemented in an eclectic way to improve emotional skills and these are consistent with the findings of the present study (Bierman, Domitrovich, Nix, Gest, Welsh, Greenberg, Blair, Nelson 
and Gill, 2008; Domitrovich, Cortes and Greenberg, 2007; Durmuşoğlu Saltal1, 2010).

In the social skills training program provided for the experimental group, the frequent use of activities targeting emotional and social problem solving skills is considered to have reduced children's aggressive and destructive behaviours. When they solve their problems, children firstly relive their discomfort and become successful and this way they can manage their anger. In addition, social skills training program introduces alternative ways to solve problems by offering pro-social behaviours for the prevention of problems. Also, the activities in the program to increase children's anger management skills seem to have had a positive impact on the social problem solving mean scores of the experimental group children.

Sessions in the social skills training program are based on a constant repetition and the training process takes place systematically with lessons built up on top of each other. In this way, children get a lot of pleasure from participating in the lessons and each lesson has a comprehensive content and this positively affects children's listening and attention skills. Moreover, drama activities, video modelling method and using puppets as models, stories promoting concept development and placement of posters facilitating problem solving in a way to be clearly seen by children are thought to be social skills teaching methods that are likely to contribute to the difference observed in social problem solving skills of the children in the experimental group.

Meta-analysis studies looking into the effectiveness of different training models designed to support children's social competence and social problem solving skills indicate that it is emphasized in the studies that these programs have created a significant impact on the individuals. However, it is argued that combined programs or those implemented in an eclectic way have produced more effective outcomes compared to single programs (Anliak and Dinçer, 2005). It is underlined in the literature that children participating in various social skills training programs in early childhood make good progress in their social problem solving skills and pro-social behaviours (Hutchings, Bywater, Gridley, Whitaker, Martin-Forbes and Gruffydd, 2011; Webster-Stratton, Reid and Hammond, 2001).

In this study, parental involvement is considered to be another factor that increased the effectiveness of Social Skills Training Program. In the program, there are at-work activities that parents do with their children which are intended to increase parental involvement and support children's skills at home. At the end of each session, supplementary activities recommended to be performed at home with parents were sent to children's home and parents were requested to give feedback on these activities. Also, at the beginning and end of each unit, parents were sent letters related to the target concepts and skills taught to children at school. In this way, parents were encouraged to participate in classroom activities. This sharing between the family and educational institution consolidated the cooperative activities between parents and school. These activities allowed parents to have a chance to get to better know their children and the activities might have intensified their efforts to be a positive model in their social communication with children. As reported by Catron (1993), children feel supported and more motivated to learn when parents do activities with them in and outside the classroom. The study conducted by Yaşar Ekici (2013) on the effect of parental involvement on children's social skills kind of supports the findings of the present research.

In this study, Montessori method supported by Social Skills Training Program (experimental group) was compared not only with the pure-Montessori method (control group 1) but also with the MNE Preschool Education Program (control group 2). Although MNE Preschool Program which was developed by a committee of experts is aimed at planning activities that support children's problem solving skills and active participation by taking teachers beyond the traditional subject teaching to the objectives and target behaviours, it is seen that these goals are not fully achieved in practice (Anliak and Dinçer, 2005).

\section{Recommendations}

The present study concluded that Montessori method supported by Social Skills Training Program had a positive effect on preschool children's skills of understanding emotion and social problem solving. It is recommended that this method be used along with Social Skills Training Program. Children's skills of understanding feelings and their social problem solving skills were examined in this study. Future studies are recommended to explore children's peer relationships, their relationships with teachers and social environment and their attitudes of independence and responsibility. The participants in the present study were children with typical development. Researchers are advised to explore the effect of Montessori method supported by Social Skills Training Program on the development of children with special needs. In addition to Montessori method supported by Social Skills Training Program, some other alternative approaches supported by Social Skills Training Program can also be adapted and tested in our country. Adjustments and improvements can be made in the preschool education system based on the results of these studies. 


\section{References}

Anlıak, Ş., \& Dinçer, Ç. (2005). Okul öncesi dönemde kişiler arası bilişsel problem çözme becerilerinin geliştirilmesi. Eurasian Journal of Educational Research, 20, 122-134.

Ansari, A., \& Winsler, A. (2014). Montessori public school pre-K programs and the school readiness of low-income Black and Latino children. Journal of Educational Psychology, 106(4), 1066-1079. http://dx.doi.org/10.1037/a0036799

Ar1, M., \& Yaban, E. H. (2012). Age and gender differences in social problem solving skills of 9-11 year-old children. Education and Science, 37(164), 188-203.

Avcığlu, H. (2005). Etkinliklerle Sosyal Beceri Öğretimi. (2. Baskı). Ankara: Kök Yayıncılı.

Bierman, K. L., Domitrovich, C. E., Nix, R. L., Gest, S. D., Welsh, J. A., Greenberg, M. T., ... (2008). Promoting academic and social-emotional school readiness: The Head Start REDI Program. Child Development, 79(6), 1802-1817. http://dx.doi.org/10.1111/j.1467-8624.2008.01227.x

Biggam, F., \& Power, K. ( 1999). A comparison of the problem-solving abilities and psychological distress of suicidal, bullied and protected prisoners. Criminal Justice and Behavior, 26(2), $196-216$. http://dx.doi.org/10.1177/0093854899026002003

Büyüköztürk, Ş. (2012). Sosyal Bilimler İçin Veri Analizi El Kitabı. Ankara: Pegem Akademik Yayıncılık.

Byun, W., Blair, S. N., \& Pate, R. R. (2013). Objectively measured sedentary behavior in preschool children: Comparison between Montessori and traditional preschools. International Journal of Behavioral Nutrition and Physical Activity, 10(2), 1-7. http://dx.doi.org/10.1186/1479-5868-10-2

Çakıroğlu, W. E. (2011). Okul Öncesi Eğitimde Montessori Yaklaşımı. Ankara: Kök Yayıncılık.

Castellanos, A. G. (2002). A comparison of traditional vs Montessori education in relation to children's self-esteem, self-efficacy, and prosocial behavior. Doctoral Dissertation. Carlos Albizu University, Miami, Florida.

Catron, E. C. (1993). Early childhood curriculum. New York: John Allen Publishing Company.

Chou, M. J. (2004). Socio-Moral Development of Young Children in Constructivist and Montessori Kindergartens in Taiwan: A Study on Interpersonal Understanding of Negotiation Strategies and Shared Experiences, Unpublished Doctoral Dissertation, Auburn University, Alabama.

Coie, J. D., \& Dodge, K. A. (1998). Aggression and antisocial behavior. In W. Damon \& N. Eisenberg (Eds.), Handbook of child psychology: 5th ed.: Social, emotional and personality development (Vol. 3, pp. 779- 862). New York: Wiley.

Çokluk, Ö., Şekercioğlu, G., \& Büyüköztürk, Ş. (2010). Çok Değişkenli İstatistik SPSS ve LISREL Uygulamaları. (Birinci bask1). Ankara: Pegem Akademi Yayınları.

Dereli, E. (2008). Çocuklar için sosyal beceri eğitim programının 6 yaş çocukların sosyal problem çözme becerilerine etkisi. Yayınlanmamış doktora tezi. Selçuk Üniversitesi, Sosyal Bilimler Enstitüsü, Konya.

DeVries, R., \& Göncü, A. (1987). Interpersonal relations in four-year olds in Dyads from Constructivist and Montessori programs. Journal of Applied Developmental Psychology, $481-501$. http://dx.doi.org/10.1016/0193-3973(87)90035-9

Domitrovich, C. E., Cortes, R. C., \& Greenberg, M. T. (2007). Improving young children's social and emotional competence: A randomized trial of the preschool "PATHS"curriculum. The Journal of Primary Prevention, 28(2), 67-91. http://dx.doi.org/10.1007/s10935-007-0081-0

Dunn, J., \& Hughes, C. (1998). Young children's understanding of emotions within close relationships. Cognition and Emotion, 12, 171-190. http://dx.doi.org/10.1080/026999398379709

Durmuşoğlu, S. N. (2010). Duygu ĕgitiminin okul öncesi dönem çocuklarının duygusal becerilerine etkisi. Yayınlanmamış doktora tezi. Selçuk Üniversitesi, Sosyal Bilimler Enstitüsü, Konya.

Durmuşoğlu, S. N., Deniz, M. E., Çeliköz, N., \& Arı, R. (2009). Altı yaş çocukları için duygusal becerilerin değerlendirilmesi testi'nin (aces) Türkçe’ye uyarlanması: Geçerlik ve güvenirlik çalışması. Ankara Üniversitesi Ĕ̈itim Bilimleri Fakültesi Dergisi, 42(1), 403-420.

Durualp, E., \& Aral, N. (2010). Altı yaşındaki çocukların sosyal becerilerine oyun temelli sosyal beceri eğitiminin etkisinin incelenmesi. Hacettepe Üniversitesi Eğitim Fakültesi Dergisi, 39, 160-172.

Flynn, T. M. (1991). Development of social, personal and cognitive skills of preschool children in Montessori and traditional preschool programs. Early Child Development and Care, 72(1), 117-124. http://dx.doi.org/10.1080/0300443910720111 
Franc, B., \& Subotic, V. (2015). Differences in phonological awareness of five-year-olds from Montessori and regular program preschool institutions. The Faculty of Teacher Education University of Zagreb Conference - Researching Paradigms of Childhood and Education, 13th - 15th April 2015/ Opatija, Croatia.

Giren, S. (2013). Sosyal problem çözme eğitiminin altı yaş çocuklarının matematik becerilerine etkisi. Yayınlanmamış Doktora Tezi. Selçuk Üniversitesi, Sosyal Bilimler Enstitisü, Konya.

Glenn, C. M. (2003). The longitudinal assessment study (LAS): Eighteen year follow-up. Final Report. Eric Document Number: ED478792. Retrieved July 30, 2007, from ERIC database.

Gunter, L., Caldarella, P., Korth, B. B., \& Young, K. R. (2012). Promoting social and emotional learning in preschool students: Study of Start Pre-K. Early Childhood Education Journal, 40, 151-159. http://dx.doi.org/10.1007/s10643-012-0507-z

He, H. L., Yan, H., Zuo, L., Liu, L., \& Zhang, X. P. (2009). Effects of Montessori education on the intellectual development in children aged 2 to 4 years. Chinese journal of contemporary pediatrics, 11(12), 1002-1005.

Hendron, R. (2011). The social development of the child in the mixed aged setting. Retrived From: http://montessoricommons.cc/the-social-development-of-the-child-in-the-mixed-aged-setting/

Hobbs, A. (2008). Academic achievement: Montessori and non-Montessori private school settings. Doctoral Dissertation. University of Houston, Houston.

Hutchings, J., Bywater, T. J., Gridley, N., Whitaker, C. J., Martin-Forbes, P., \& Gruffydd, S. (2011). The incredible years therapeutic social and emotional skills programme: A pilot study. School Psychology International, 33(3), 285-293. http://dx.doi.org/10.1177/0143034311415899

Jarvis, J. (2015). The association between preschool type and children's concentration abilities. Honors Projects. Bowling Green State University, Ohio, USA.

Kayıl1, G., \& Ar1, R. (2011). Examination of the effects of the Montessori method on preschool children's readiness to primary education. Educational Sciences: Theory \& Practice, 11(4), 2091-2109.

Kayılı, G., \& Kuşcu, Ö. (2012). Examination of social competence and school adjustment of primary school children who had pre-school education with the Montessori method. Journal of Teaching and Education, 1(2), 399-405.

Kayılı, G., Koçyiğit, S., \& Erbay, F. (2009). Montessori yönteminin beş - altı yaş çocuklarının alıcı dil gelişimine etkisinin incelenmesi. Selçuk Üniversitesi Türkiyat Araştırmaları Dergisi, 26, 347-355.

Keçecioğlu, Ö. (2015). MEB Okul Öncesi Eğitim Programı ve Montessori Yaklaşımına göre eğitim alan 5 yaş çocuklarının sosyal becerilerinin incelenmesi. Yayınlanmamış Yüksek Lisans Tezi. Marmara Üniversitesi, Eğitim Bilimleri Enstitüsü, İstanbul.

Koçyiğit, S., \& Kayıll, G. (2008). Montessori eğitimi alan ve almayan anaokulu öğrencilerinin sosyal becerilerinin karşılaştırılması. Selçuk Üniversitesi Sosyal Bilimler Enstitüsü Dergisi, 20, 511-516.

Koçyiğit, S., Kayılı, G., \& Erbay, F. (2010). Montessori yönteminin beş - altı yaş çocuklarının dikkat toplama becerilerine etkisinin incelenmesi. Çağdaş Ĕ̈itim Dergisi, 372, 16-21.

Korkmaz, E. (2005). Montessori metodu ve Montessori okullarl: Türkiye`de Montessori okullarının yönetim ve finansman bakımından incelenmesi. Yayınlanmamış Yüksek Lisans Tezi. Marmara Üniversitesi, Eğitim Bilimleri Enstitüsü, İstanbul.

Kramer, T., Calderalle, P., Christensen, L., \& Shatzer, R. H. (2010). Social and emotional learning in the kindergarten classroom: Evaluation of the strong start curriculum. Early Childhood Education Journal, 37, 303-309. http://dx.doi.org/10.1007/s10643-009-0354-8

Lopata, C., Wallace, N., \& Finn, K. (2005). Comparison of academic achievement between Montessori and traditional educational programs. Journal of Research in Childhood Education, 20(1), 5-13. http://dx.doi.org/10.1080/02568540509594546

Morrison, G. S. (2007). Early childhood education today, (10th Edition). New Jersey: Prentice Hall.

Parker, J. G., \& Asher, S. R. (1993). Friendship and friendship quality in middle childhood: Links with peer group acceptance and feelings of loneliness and social dissatisfaction. Developmental Psychology, 29, 611-621. http://dx.doi.org/10.1037/0012-1649.29.4.611

Powless, L. D., \& Eliot, N. S. (2002). Assegment of social skills of native American preschoolers: Teachers and parent rating. University of Wisconsin, Madison, USA.

Rathunde, K., \& Csikszentmihalyi, M. (2005). The social context of middle school: Teachers, friends, and activities in Montessori and traditional school environments. The Elementary School Journal, 106(1), 59-79. http://dx.doi.org/10.1086/496907 
Reid, M. J., Webster-Stratton, C., \& Hammond, M. (2007). Enhancing a Classroom Social Competence and Problem-Solving Curriculum by Offering Parent Training to Families of Moderate- to High-Risk Elementary School Children. Journal of Clinical Child \& Adolescent Psychology, 36(4), 605-620. http://dx.doi.org/10.1080/15374410701662741

Rubin, K. H., \& Krasnor, L. R. (1986). Social-cognitive and social behavioral perspectives on problem solving. In M. Perlmutter (Ed.), Cognitive perspectives on children's social and behavioral development. The Minnesota Symposia on Child Psychology (Vol. 18). Hillsdale, N.J.: Erlbaum (pp. 1-68).

Santrock, J. W. (2015). Yaşam boyu gelişim, gelişsim psikolojisi. (Çev. Edt: Galip Yüksel). Ankara: Nobel Akademi.

Shure, M. B., \& Spivack, G. (1982). Interpersonal problem-solving in young children: A cognitive approach to prevention. American Journal of Community Psychology, 10, 341-356. http://dx.doi.org/10.1007/BF00896500

Spivack, G., \& Shure, M. B. (1985). ICPS and beyond: Centripetal and centrifugal forces. American Journal of Community Psychology, 13, 226-243.

Temel, Z. F. (2005). Okul öncesi eğitimde yeni yaklaşımlar. Bilim ve Aklın Aydınlı̆ğnda Eğitim Dergisi, 62. Retrived from http//yayim.meb.gov.tr/dergiler/sayi62/temel.htm

Thomas, J. (2008). Child development programs. EBSCO Research Starters, EBSCO Publishing Inc.

Toran, M. (2011). Montessori yönteminin çocukların kavram edinimi, sosyal uyumları ve küçük kas motor becerileri üzerindeki etkisinin incelenmesi. Yayınlanmamış Doktora Tezi. Gazi Üniversitesi, Eğitim Bilimleri Enstitüsü, Ankara.

Webster-Stratton, C. (1990). Dina Dinosaur's Social Skills and Problem-Solving Curriculum. Seattle, WA: Incredible Years.

Webster-Stratton, C. (2012). Incredible teachers: Nurturing children's social, emotional and academic competence. West Seattle: Inredible Years Inc.

Webster-Stratton, C., \& Reid, M. J. (2004). Strengthening social and emotional competence in young children-The foundation for early school readiness and success, Incredible years classroom social skills and problem-solving curriculum. Infants and Young Children, 17(2), 96-113. http://dx.doi.org/10.1097/00001163-200404000-00002

Webster-Stratton, C., Reid, M. J., \& Beauchaine, T. P. (2013). One-year follow-up of combined parent and child intervention for young children with ADHD. Journal of Clinical Child and Adolescent Psychology, 42, 251-261. http://dx.doi.org/10.1080/15374416.2012.723263

Webster-Stratton, C., Reid, M. J., \& Hammond, M. (2001). Preventing conduct problems, promoting social competence: A parent and teacher training partnership in Head Start. Journal of Clinical Child Psychology, 30(3), 283-302. http://dx.doi.org/10.1207/S15374424JCCP3003_2

Webster-Stratton, C., Reid, M. J., \& Stoolmiller, M. (2008). Preventing conduct problems and improving school readiness: Evaluation of the Incredible Years teacher and child training programs in high-risk schools. Journal of Child Psychology and Psychiatry, 49(5), 471-488. http://dx.doi.org/10.1111/j.1469-7610.2007.01861.x

Werner, N. E., \& Crick, N. R. (2004). Maladaptive peer relationships and the development of relational and physical aggression during middle childhood. Social Development, 13(4), 495-514. http://dx.doi.org/10.1111/j.1467-9507.2004.00280.x

Yaban, H., \& Yükselen, A. (2007). Korunmaya muhtaç yedi-onbir yaş grubu çocuklarının sosyal problem çözme becerilerinin incelenmesi. Toplum ve Sosyal Hizmet Dergisi, 18(1), 49-68.

Yaşar Ekici, F. (2013). Okul öncesi eğitim kurumlarındaki aile katılım çalışmalarına katılan ve katılmayan ailelerin çocuklarının sosyal beceriler açısından karşılaştııılması. İZÜ Sosyal Bilimler Dergisi, 2(3), 167-186.

Yiğit, T. (2008). Okulöncesi eğitim kurumlarında Montessori ve geleneksel ögretim yöntemleri alan çocukların sayı kavramını kazanma davranışlarının karşılaştırılması. Yayınlanmamış Yüksek Lisans Tezi. Selçuk Üniversitesi, Sosyal Bilimler Enstitüsü, Konya.

Yıldırım, D. S. S. (2015). Efficacy of Montessori education in attention gathering skill of children. Educational Reseach and Reviews, 10(6), 733-738. http://dx.doi.org/10.5897/ERR2015.2080

Yılmaz, E. (2012). 60-72 aylık çocukların duyguları anlama becerilerinin sosyal problem çözme becerilerine etkisinin incelenmesi. Yayınlanmamış yüksek lisans tezi. Selçuk Üniversitesi, Sosyal Bilimler Enstitüsü, Konya.

\section{$(\infty))_{\text {BY }}$}

This work is licensed under a Creative Commons Attribution 3.0 License. 